\title{
Penerapan Kontrol Fuzzy Logic Berbasis Matlab Pada Perangkat Mesin Cuci
}

\author{
Hendri D. Putra, Matias K. Kelviandy, Bintang E. Pute ra \\ Universitas Gunadarma \\ Depok, Indonesia \\ hendri_dp@staff.gunadarma.ac.id, matias_kk@staff.gunadarma.ac.id, bintang_ep@ @staff.gunadarma.ac.id
}

\begin{abstract}
Abstrak - Pemanfaatan Fuzzy logic dalam implementtasi perangkat seringkali menjadi pilihan terbaik karena dapat menjembatani bahasa manusia yang cenderung tidak presisi dengan bahasa mesin yang cenderung presisi. Dalam pemanfaatannya terhadap implementasi kendali kecepatan mesin cuci sesuai dengan beban dan tingkat kekotoran pakaian tertentu, metode ini jelas berhasil untuk membuat kecepatan putaran mesin cuci lebih optimal. Kendali tidak menitikberatkan pada angka, tetapi menekankan pada suatu nilai semesta pembicaraan. Sehingga respon kecepatan yang dihasilkan sesuai dengan toleransi dari input dan menciptakan kenaikan sinyal grafik yang dihasilkan untuk mendapatkan suatu peningkatan kecepatan yang optimal.
\end{abstract}

Kata Kunci: Fuzzy Logic, Mesin Cuci, Kecepatan, Kendali.

\section{PENDAHULUAN}

Fuzzy logic sudah berkembang dalam konsep sistem kendali dalam segala bidang, fuzzy logic dalam arti logika dengan tingkat kebenaran tinggi, menjadi alternatif terbaik dalam mengendalikan, mengatur, menggerak, menjalankan suatu pengendalian sistem yang berfungsi untuk mempermudah manusia dalam menyelesaikan suatu masalah.

Fuzzy logic seringkali menjadi pilihan terbaik karena mempunyai beberapa kelebihan, antara lain dapat menjembatani bahasa manusia yang cenderung tidak presisi dengan bahasa mesin yang cenderung presisi, karena fuzzy logic dibangun berdasarkan pada bahasa manusia. Penggunaan fuzzy logic lebih mudah dengan adanya bahasa pemrograman Matlab, yang dapat mensimulasikan suatu sistem fuzzy, dengan hasil analis is dapat berupa sinyal grafik pada fitur scope.

Fuzzy logic dapat digunakan pada benda yang bekerja pada suatu sistem otomatis, misalnya pada mesin cuci, fuzzy logic dapat mengatur kendali kecepatan mesin cuci sesuai dengan beban dan tingkat kekotoran pakaian tertentu, jika beban dan tingkat kekotoran pakaian bertambah besar, maka kecepatan yang dihasilkan akan semakin besar juga.

Percobaan sistem kendali fuzzy logic dalam mesin cuci pernah dilakukan dalam penelitian oleh Frans kurniadi (2004), dimana berdasarkan penelitiannya, dengan mekanis me variabel berat 0 $7,5 \mathrm{Kg}$, intensitas cahaya untuk mengasumsikan tingkat kekotoran pakaian dengan nilai $0-50$ lux satuan cahaya, dan kecepatan yang dikontrol dengan nilai $0-23,3 \mathrm{rad} / \mathrm{sec}$.

Hasil dari penelitian tersebut berupa kecepatan yang stabil, dalam arti kecepatan yang dihasilkan oleh sinyal grafik pada fitur scope matlab mengalami rise time yang sama, yaitu setiap 0,02 detik pada jalannya waktu simulasi, yang menandakan bertambah-nya variabel masukan yaitu beban dan kotor pakaian, tetapi dalam penggunaan fuzzy logic mekanisme ini belum optimal, karena fuzzy logic tidak selalu men itikberatkan pada angka, dan hasil yang didapat memungkinkan mendapat acuan dari nilai crisp, yaitu adanya himpunan (kecepatan) yang sama walaupun sudah mengalami kenaikan harga/nilai dari variabel input, sehingga kecepatan yang dihasilkan dapat tidak sesuai dengan fungsi keanggotaanya.

Penelitian ini dilakukan untuk mencoba mengembangkan dari peneliti-an yang sebelumnya, dimana hasil yang diharapkan dapat membuat kecepatan mesin cuci lebih optimal, dalam arti kecepatan yang dihasilkan bersifat fuzzy, yaitu tidak menitikberatkan pada angka, tetapi menekankan pada suatu nilai semesta pembicaraan (nilai berada di antara 0 dan 1), sehingga respon kecepatan yang dihasilkan sesuai dengan toleransi dari input, berupa beban dan tingkat kekotoran pakaian, bertambah besar nilai toleransi input, bertambah besar/panjang juga tingkat kenaikan sinyal grafik yang dihasilkan.

\section{LANDAS AN TEORI}

A. Fuzzy Logic 
Fuzzy logic di dalam istilah kamus besar diartikan sebagai blurred (kabur atau remangremang), indistinct (tidak jelas), confused (membingungkan), istilah-istilah ini bukan berarti menggambarkan sistem yang tidak jelas/kabur/ remang-remang, akan tetapi, istilah fuzzy logic bekerja sebagai sebuah sistem fuzzy yang digunakan pada perancangan sistem dengan cara kerja dan deskripsi yang ditujukan untuk membantu memperoleh pemecahan dari masalah dengan cepat dan efisien. Mentransfer kecerdasan manusian ke dalam sebuah komputer atau mesin lebih mudah dilakukan menggunakan fuuzy logic, Saat ini, implementasinya sering digunakan pada perangkat seperti mesin cuci, kamera, microwave, dan lainlain[1].

\section{B. Himpunan Fuzzy}

Himpunan fuzzy merupakan sebuah gagasan utama yang digunakan untuk memperluas jangkauan sebuah fungsi hingga mencakupi bilangan nyata pada interval [0.1]. Nilai semesta yang disebutkan adalah sebuah nilai fuzzy, nilai ini tidak hanya pada angka pasti, dimana nilai 0 dapat berarti salah atau sebagai nilai paling minimum, sedangkan nilai 1 berarti benar atau nilai paling maksimum, fuzzy beroperasi pada nilai yang terletak diantara nilai tersebut. Himpunan fuzzy merupakan himpunan yang berlawanan dengan nilai crisp, yakni nilai yang didefinisikan oleh nilainilai terdapat di dalam himpunan itu, misalnya jika terdapat nilai "a" merupakan anggota dari himpunan "A", maka nilai yang berkaitan dengan nilai "a" memiliki nilai 1 , sedangkan nilai yang tidak berhubungan dengan nilai "a" mempunyai nilai 0. [7]

Fuzzy logic pada kemampuannya untuk menekankan sebuah makna atau arti (significance) dapat menjadi jembatan dari bahasa mesin yang sangat presisi dengan bahasa yang digunakan oleh manusia yang memiliki presisi rendah. Menggunakan fuzzy logic, sebuah sistem kepakaran manusia dapat ditanam ke dalam bahasa mesin dengan mudah dan efisien. Gambar 1 merupakan fungsi dari sistem fuzzy sebagai sebuah ilustrasi, dimana terdapat bahasa presisi (dengan bilangan) yang digunakan dan bahasa kata-kata. Manusia cenderung kesulitan mengartikan bahasa presisi yang dibutuhkan oleh mesin, sebagai lawannya, manusia lebih mudah mengartikan istilah/variabel perkataan yang jauh lebih sederhana dan singkat. Dalam hal ini, fuzzy dapat diimplementasikan sebagai fungsi yang dapat menjembatani komunikasi antara mesin dengan manusia agar menjadi lebih efektif dan efisien antara mesin dan manusia[1].

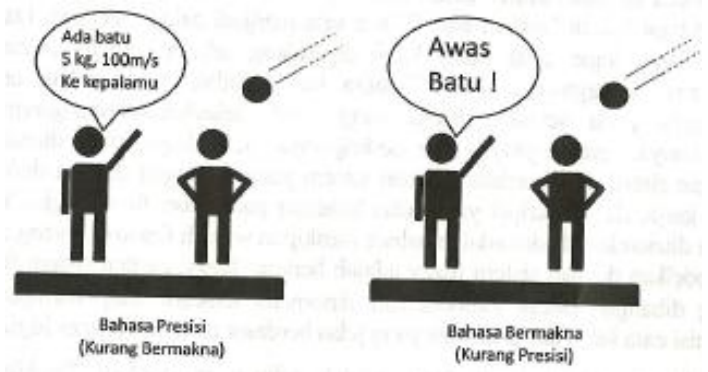

Gambar 1 Bahasa Presisi dan Bahasa Bermakna[1]

Pengendali fuzzy umumnya digunakan karena handal, mudah diperbaiki, dan dapat memberikan pengendalian yang sangat baik jika dibandingkan dengan teknik sejenis yang biasanya butuh usaha dan dana yang tidak kecil.

\section{Fuzzy Inference System (FIS)}

Fuzzy logic memiliki prinsip kerja sebagai pemetaan area input ke dalam area output dengan menerapkan aturan IF-THEN. Gambar 2 menjelaskan logika pemetaan hubungan antara input dengan output. Di tengah antara input dengan output terdapat sebuah blok yang disebut black box. Bagian ini bertugas melakukan pemetaan. Fuzzy Inference System (FIS) memiliki beberapa aturan dengan urutan yang dapat sembarang. aturan ini digunakan untuk menghasilkan sebuah kesimpulan. Oleh sebab itu, seluruh aturan harus ditentukan lebih awal jika membuat sebuah FIS yang mengimple mentasikannya.

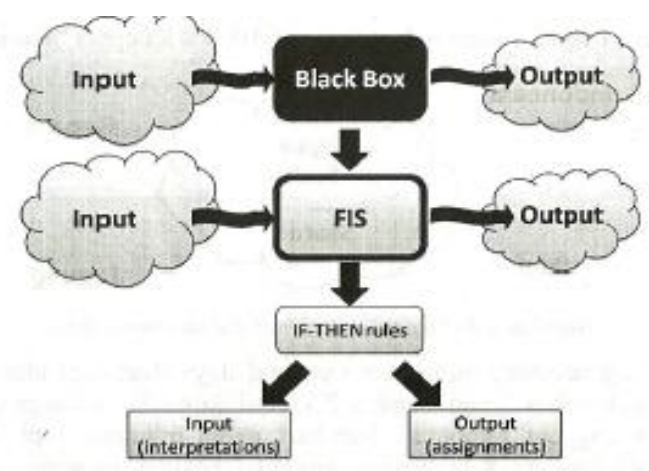

Gambar 2 Konsep Umum Pembangunan FIS [1]

FIS dapat disebut sebagai metode yang melakukan interpretasi nilai di dalam vektor input dan menghasilkan kesimpulan dari aturan IF-THEN yang diterapkan, kemudian FIS akan menghasilkan nilai pada vektor output. FIS dapat diimplementasikan ke dalam beberapa bidang, misalnya kendali oto matis, klasifikasi data, analis is keputusan, dan sistem pakar[1].

D. Matlab (Matrix Laboratory) 
Matlab merupakan sebuah bahasa pemrograman tingkat tinggi yang arti perintah dan fungsi-fungsinya lebih mudah dipahami. Di awal penggunaannya, matlab dapat menangani bermacam-macam operasi matriks dan vektor menggunakan berbagai rutin dan pustaka LINPACK dan EISPACK. Saat ini Matlab lebih berkembang karena berbagai masukan dari banyak penggunanya. Matlab di dalam dunia akademis pada bidang perkuliahan menjadi perangkat bantu standar instruksional dan pada bidang matematika, keilmuan dan teknik menjadi perangkat bantu instruksional tingkat lan jut.

Matlab terdiri dari beberapa jenis toolbox dimana didalamnya terdapat bermacam bidang keilmuan yang lebih khusus, seperti kecerdasan buatan (fuzzy logic, neural network, control system, signal processing dan wavelet).

Matlab memiliki bermacam kemudahan untuk dipelajari dan digunakan untuk merancang seuah sistem kendali. Matlab akan menghasilkan keluaran yang beragam, salah satunya adalah analisis grafik dari perilaku sebuah sistem kendali dengan metode yang diterapkan[4].

\section{E. Fuzzy Logic Toolbox}

Fuzzy Logic Toolbox merupakan sekumpulan tool yang dapat digunakan dalam perancangan sistem fuzzy. Perangkat ini juga dapat digunakan untuk membuat atau mengubah FIS (Fuzzy Inference System) pada lingkungan kerja Matlab. Tool ini mudah untuk digunakan dimana pengguna dapat berkreasi dengan bebas saat melakukan rancang bangun sistem FIS. Fuzzy Logic Toolbox memiliki 5 jenis Graphic user Interface (GUI), yakni:
1. FIS Editor
3. Rule Editor
4. Rule Viewer
5. Surface viewer

2. Membership Function Editor

FIS Editor, Membership Function Editor, dan Rule Editor memiliki fungsi untuk membaca dan memodifikasi data yang sudah ada, sedangkan tool Rule Viewer dan Surface Viewer hanya memiliki fungsi untuk pembacaan data dimana modifikasi melalui perangkat ini tidak dapat dilakukan jika terjadi kesalahan.

Semua GUI yang telah disebutkan saling terikat dan mempengaruhi, dimana perubahan yang dilakukan pada GUI satu akan mempengaruhi GUI lain[1].
Dalam penelitian ini, metode penelitian yang digunakan adalah metode studi pustaka, analisis dan perbandingan (comparison). Metode studi pustaka, peneliti mengambil sumber teori pendukung yang sesuai dengan judul penelitian, baik sumber yang berupa buku, atau berupa jurnal. Metode analisis menjabarkan bagaimana suatu fuzzy logic dapat bekerja untuk mengendalikan kecepatan pada mesin cuci, sehingga dapat mendapat suatu kesimpulan faktor-faktor yang mempengaruhi suatu output. Metode perbandingan (comparison) membandingkan hasil kesimpulan dari yang penulis buat, dengan hasil kesimpulan dari percobaan yang dilakukan peneliti sebelumnya.

\section{PERANCANGAN}

\section{A. Perancangan Model}

Perancangan model merupakan suatu rancangan awal sistem untuk membuat simulasi. Simu lasi yang dirancang adalah simulasi mesin cuci yang diberikan pengendalian fuzzy logic untuk mengon-trol kecepatan sesuai dengan toleransi yang diberikan oleh input. Fuzzy logic pada sistem ini sebagai penentu nilai setpoint yaitu harga yang diinginkan bagi variabel yang dikontrol selama pengontrolan.

Sistem yang digunakan untuk simulasi ini adalah sistem tertutup, dimana adanya perbandingan dari nilai output sebagai sinyal umpan balik dengan nilai input yang masuk, seperti Gambar 3 berikut.

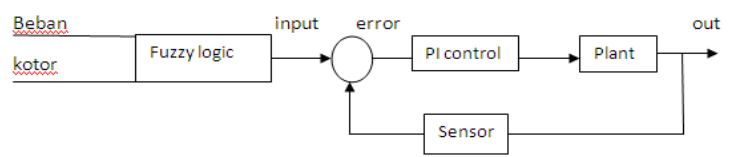

Gambar 3 Sistem Fuzzy Logic Sebagai Setpoint

Pada Gambar 3 di atas terlihat jelas bahwa beban dan kotor sebagai input variabel, nilai dari kedua input ini akan ditoleransi untuk selanjutnya diproses. Toleransi dari input tersebut diproses fuzzy logic untuk mengontrol putaran motor pada mesin cuci dan menghasilkan nilai setpoint. Sedangkan PI Control untuk memproses kesalahan (error) yang masuk setelah melalui elemen pengontrol yaitu fuzzy logic, di bagian ini juga dapat di tentukan nilai konstanta ( $\mathrm{kp}$ dan ki) yang akan terintegritas oleh nilai hasil dari proses fuzzy logic untuk menghasilkan suatu hasil yang optimal.

Plant adalah model sistem yang digunakan untuk menjalankan suatu rancangan sistem, misalnya untuk plant pada mesin cuci adalah perancangan desain flux vektor yang didalamnya berisi vektor kontrol untuk membuat suatu motor sistem.

\section{METODE PENEL ITIAN}


Sensor merupakan elemen yang mengontrol sinyal umpan balik keluaran untuk di selisihkan dengan nilai setpoint.

Error adalah selisih antara nilai setpoint dan umpan balik masukan dari sensor.

\section{B. Desain Flux Vektor}

Beberapa vektor control diagram yang digunakan untuk desain Flux, yaitu:

- Blok Speed Controller

- Current calculation Diagram

- Transformation Diagram

- Flux Calculation diagram

- Teta Calculation Diagram

1) Blok Speed Controller

Matlab menyediakan suatu fungsi blok dengan menggunakan transformasi $z$, blok in $i$ berfungsi untuk menentukan fungsi transfer pada sistem yang didapat dari Te (Torsi elektro magnetik) yang merupakan fungsi dari arus stator dan arus rotor, sehingga dapat dihasilkan.

$\mathrm{e}=\mathrm{W}^{*}-\mathrm{Wm}$

$\mathrm{Te}=\mathrm{Kp} \mathrm{e}+\mathrm{Ki} \int e d t$

atau

kontrol PI $=\mathrm{Kp}+\mathrm{Ki} / \mathrm{z}$

Dengan z sebagai transformasi bilinear $\left(\frac{T(z+1)}{2(z-1)}\right)$

Dari persamaan diatas dihasilkan fungsi transfer :

$$
\mathrm{G}(\mathrm{z})=\mathrm{Te}=\mathrm{Kp} * \mathrm{e}+\mathrm{Ki}\left(\frac{T(z+1)}{2(z-1)}\right) * \mathrm{e}
$$

Diasumsikan nilai $\mathrm{Kp}=75$ dan $\mathrm{Ki}=50$, sehingga

$$
\mathrm{G}(\mathrm{z})=75 \mathrm{e}+50 \mathrm{e}\left(\frac{T(z+1)}{2(z-1)}\right)
$$

\section{2) Current calculation Diagram}

Blok ini terdiri dari dua bagian yaitu $\mathrm{Id}^{*}$ sebagai fluks motor controlled dan Iq* berfungsi sebagai pengontrolan torque motor dengan nilai bergantung pada Phir* dan Te*. Te* (torsi elektromagnetik) didapat dari blok speed controller dimana terdapat PI control, dengan perbandingan KP :KI yaitu 75 : 50, dan torque motor 300N.m. sedangkan nilai $\mathrm{Ph}$ ir $^{*}$ tergantung pada slip motor induksi, yang ditentukan sebesar 0.96. Hasil dari blok ini berupa arus yang dipakai untuk DQ-ABC.

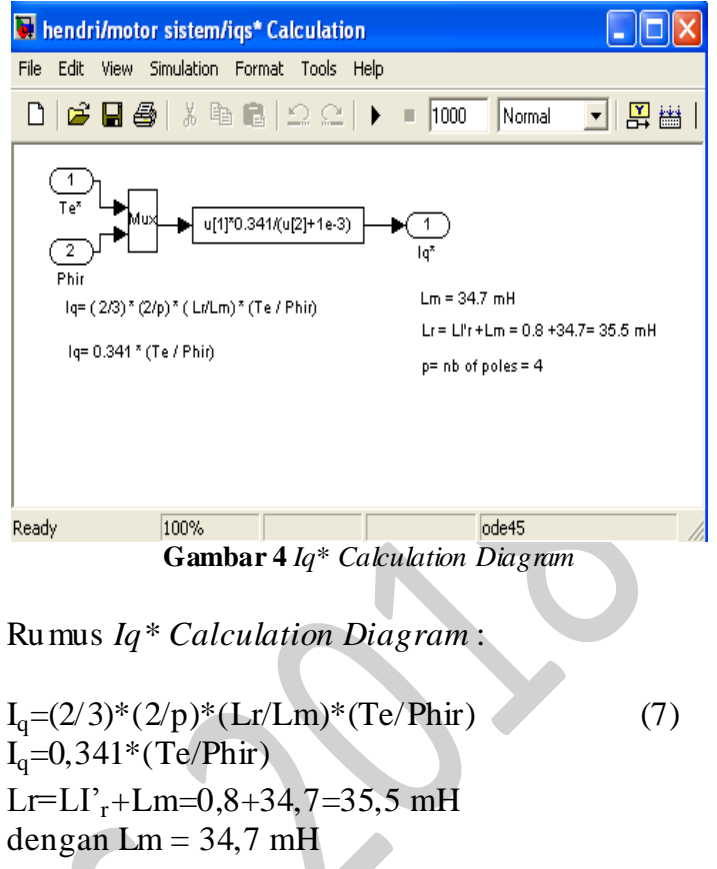

7. File Edit View Simulation Format Tools Help

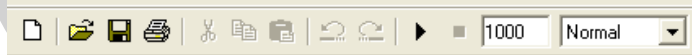

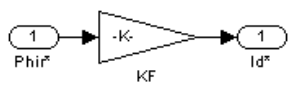

Id $\mathrm{d}^{\mathrm{x}}=\mathrm{Phir}^{\mathrm{r}} / \mathrm{Lm}$ $L \mathrm{~m}=34.7 \mathrm{mH}$

Rumus $I d^{*}$ Calculation Diagram:

$\mathrm{Id}^{*}=\mathrm{Ph}$ ir*/Lm

dengan $\mathrm{Lm}=34,7 \mathrm{mH}$

\section{3) Transformation Diagram}

Blok ini terdiri dari dua blok utama, yaitu Blok ABC-DQ dan Blok DQ-ABC. Blok DQ-ABC mengubah current Direct-Quadratic references menjadi current references $\mathrm{Ia}^{*}, \mathrm{Ib}^{*}$, Ic*, yang menjadi input current regulator. Sebaliknya, Blok ABC-DQ mengubah arus Current $\mathrm{Ia}^{*}, \mathrm{Ib}^{*}, \mathrm{Ic}^{*}$ yang terukur di stator, menjadi current DQ.

Kedua Transformation Diagram merupakan satu kesatuan fungsi dan tidak bisa berdiri sendiri karena saling bergantung satu dengan yang lain. 


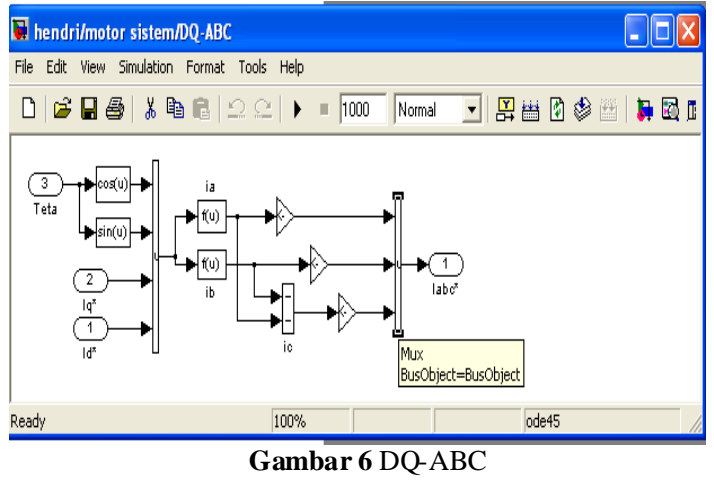

Transformasi tegangan dq-to-abc:

$\left[\begin{array}{c}V_{q s} \\ V_{d s}\end{array}\right]=\frac{1}{3}\left[\begin{array}{c}2 \cos \theta \cos \theta+\sqrt{3} \sin \theta \\ 2 \sin \theta \cos \theta+\sqrt{3} \cos \theta\end{array}\right]\left[\begin{array}{c}V_{a b s} \\ V_{b c s}\end{array}\right]$

Tranformasi arus dq-to-abc :

$\left[\begin{array}{l}i_{a s} \\ i_{b s}\end{array}\right]=\left[\begin{array}{ll}\cos \theta & \sin \theta \\ \frac{-\cos \theta+\sqrt{3} \sin \theta}{2} & \frac{-\sqrt{3} \cos \theta-\sin \theta}{2}\end{array}\right]\left[\begin{array}{l}i_{q s} \\ i_{d s}\end{array}\right]$

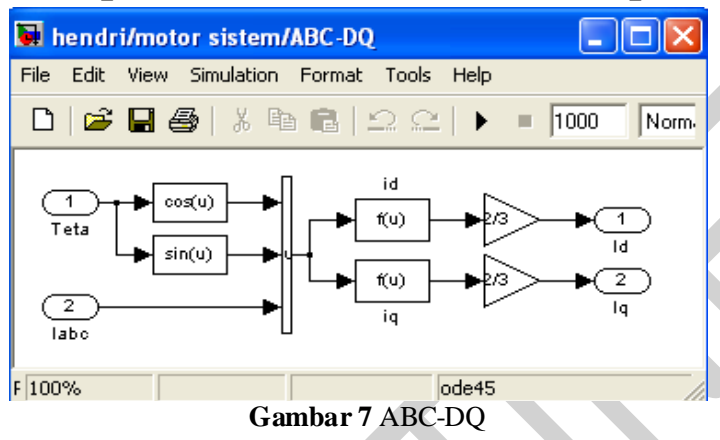

Transformasi tegangan abc-to-dq :

$\left[\begin{array}{c}\mathrm{V}_{\mathrm{qr}}^{\prime} \\ V^{\prime}{ }_{d r}\end{array}\right]=\frac{1}{3}\left[\begin{array}{c}2 \cos \theta \cos \beta+\sqrt{3} \sin \beta \\ 2 \sin \beta \sin \beta-\sqrt{3} \cos \beta\end{array}\right]\left[\begin{array}{c}V^{\prime}{ }_{a b r} \\ V_{b c r}^{\prime}\end{array}\right]$

Transformasi arus abc-to-dq

$\left[\begin{array}{l}i_{a r}^{\prime} \\ i_{b r}^{\prime}\end{array}\right]=\left[\begin{array}{ll}\cos \beta & \sin \beta \\ \frac{-\cos \beta+\sqrt{3} \sin \beta}{2} & \frac{-\sqrt{3} \cos \beta-\sin \beta}{2}\end{array}\right]\left[\begin{array}{l}i_{q s} \\ i_{d s}\end{array}\right]$

\section{4) Flux Calculation Diagram}

Blok flux calculation merupakan bagian yang berfungsi untuk menghitung besaran flux kemudian hasil dari bagian ini adalah Phir yang dipakai untuk menghitung iq* calculation setiap saat. Discrete transfer function merupakan bagian yang paling penting dalam blok ini karena terdapat rumus untuk menghitung besaran flux. Transfer function yang muncul karena perubahan yang terjadi setiap saat adalah orde satu dengan periode $0.1557 \mathrm{~s}$ (dari perhitungan $\mathrm{Lr} / \mathrm{Rr}$ ) dipakai untuk mengintegrasikan perkalian id dan Lm menjadi Phir.

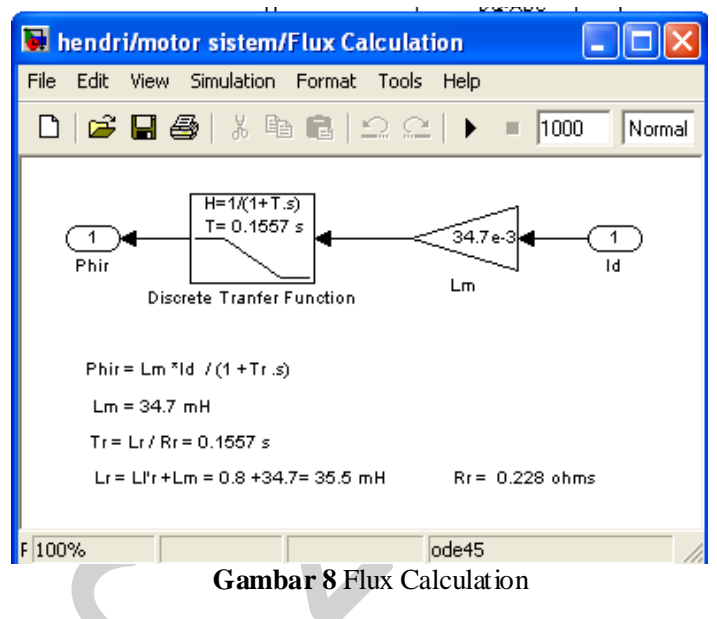

Rumus Flux Calculation Diagram:

Phir $=\mathrm{Lm}^{*} \mathrm{i}_{\mathrm{d}} /\left(1+\mathrm{T}_{\mathrm{r}} \mathrm{s}\right)$

dengan $\mathrm{Lm}=34,7 \mathrm{mH}$

$\operatorname{Tr}=\mathrm{Lr} / \mathrm{Rr}=0,1557 \mathrm{~s}$

dengan $\mathrm{Rr}=0,228 \mathrm{oh} \mathrm{ms}$

$\mathrm{Lr}=\mathrm{LI}^{*} \mathrm{r}+\mathrm{Lm}=0,8+34,7=35,5 \mathrm{mH}$

\section{5) Teta Calculation Diagram}

Blok ini berfungsi untuk menghitung nilai sudut antara rotor dan stator dalam fungsi sudut radian. Pada bagian ini diperlukan parameter Iq* dan Phir dan rotor mechanical speed (wm).

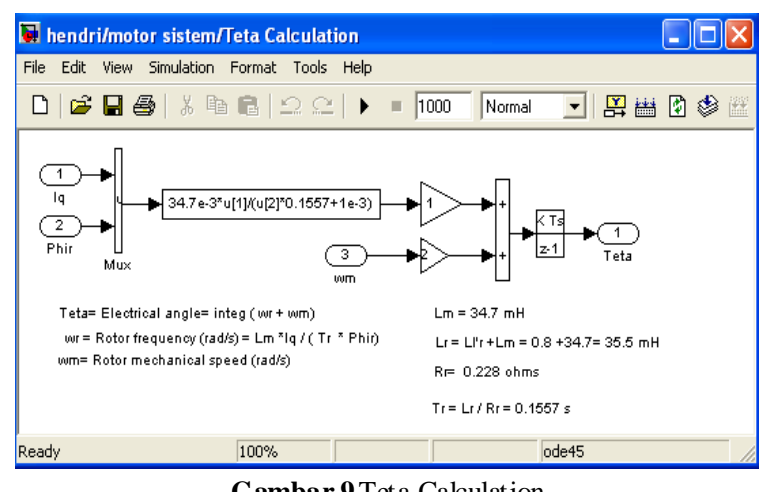

Rumus Teta Calculation

Teta $=$ Electrical angle $=$ Integ $(\mathrm{wr}+\mathrm{wm})$

$\mathrm{wr}=$ rotor frequency $(\mathrm{rad} / \mathrm{ssec})$

$=\mathrm{Lm}^{*} \mathrm{i}_{\mathrm{q}} /\left(\mathrm{Tr}^{*}\right.$ Phir $) \mathrm{dan}$

$\mathrm{wm}=$ rotor mechanical speed $(\mathrm{rad} / \mathrm{sec})$ 
$\mathrm{Lr}=\mathrm{LI}^{*} \mathrm{r}+\mathrm{Lm}=0.8+34,7=35,5 \mathrm{mH}$ dan $\mathrm{Tr}=\mathrm{Lr} / \mathrm{Rr}=0,1557 \mathrm{~s}$ dengan $\mathrm{Rr}=0,228 \mathrm{oh} \mathrm{ms}$

$\theta_{e}=\int\left(\omega_{m}+\omega_{s l}\right) d t$ Transformasi ke $\mathrm{z}=\frac{T}{z-1}$

6) Simulasi Dengan Menggunakan Simulink Matlab

Setelah mendefinisikan desain flux vektor tersebut jika di rancang simulasi dalam simulink mat lab maka akan dihasilkan blok motor.

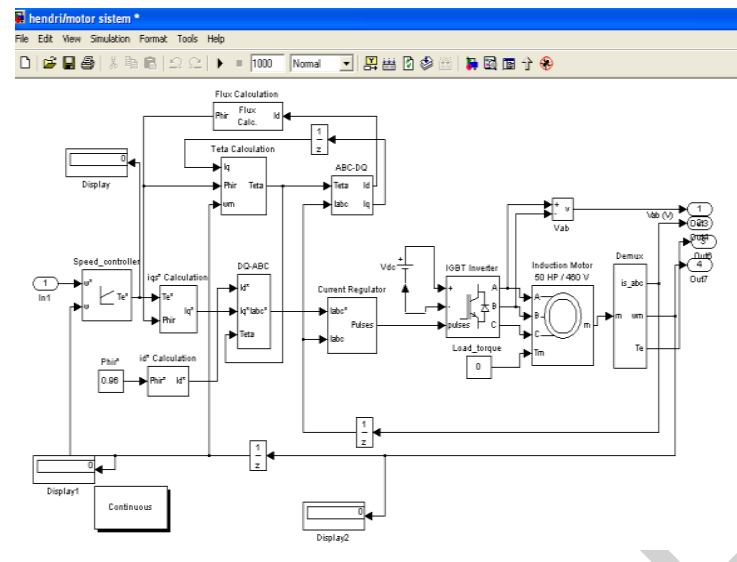

Gambar 10 Blok Motor Sistem

Gambar 10 adalah blok motor sistem yang di dalam nya terdapat desain plant yang berfungsi untuk mengintegrasi fuzzy logic control dengan pengontrolan PI (proportional integrated) yang terdapat pada blok speed controller untuk menghasilkan suatu grafik sinyal yang optimal.

Jika secara keseluruhan sistem simulasi mesin cuci dengan menggunakan fuzzy logic control telah selesai didefin isikan, maka tampilan pada Simulink Matlab sebagai berikut:

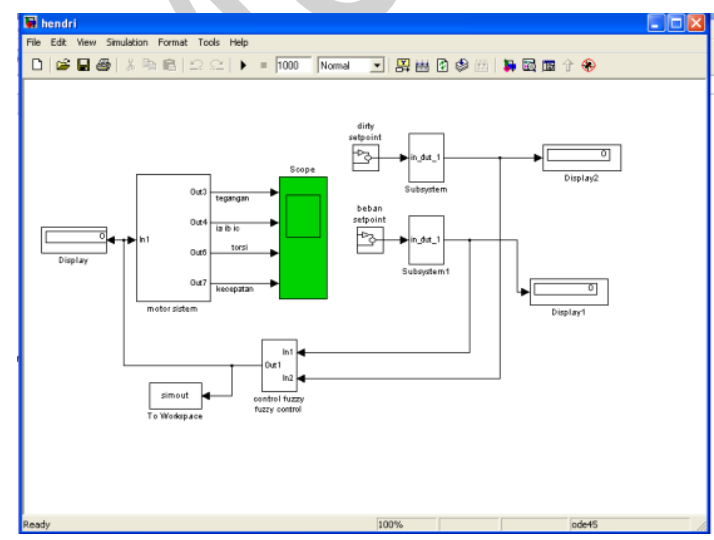

Gambar 11 Simulasi Mesin Cuci Pada Simulink Mat lab
Gambar 11 merupakan simulasi dari perancangan untuk mengatur kecepatan pada mesin cuci dengan menggunakan fuzzy logic control. Icon terdiri dari variable kotor dan beban, untuk menghasilkan nilai setpoint maka toleransi dari input tersebut diproses dalam fuzzy control yang didalamnya terdapat FIS editor yang telah dirancang, keluaran dari fuzzy control masuk ke dalam motor sistem.

Hasil akhir dari simulasi ini berupa grafik sinyal yang dihasilkan motor sistem yaitu Tegangan, Ia Ib Ic, Torsi, dan kecepatan yang merupakan hasil dari proses fuzzy logic control.

Pada Simulink terdapat display icon digunakan untuk menampilkan subsystem dari setiap input, pada saat simulasi dijalankan display icon ini akan menunjukkan angka-angka sebagai tanda input telah berjalan.

\section{HAS IL dan PEMBAHASAN}

\section{A. Hasil yang Diharapkan}

Setelah meneliti hasil yang didapat dari penelitian sebelum nya, penulis mencoba mengoptimalkan hasil yang diharapkan, yaitu kecepatan yang didapat sesuai dengan fungsi keanggotaan, dengan menggunakan mekanisme nilai semesta pembicaraan, yaitu nilai tidak dititikberatkan pada angka, tetapi berdasar pada nilai diantara nilai 0 dan 1 , nilai 0 berarti input yang minimum yaitu dimulai dari tidak ada beban dan tidak ada tingkat kekotoran, sedangkan nilai satu nilai maksimal, yaitu beban dan tingkat kekotoran maksimal sesuai dengan standar mesin cuci. Nilai semesta diberikan pada semua elemen baik input maupun output, dengan nilai fungsi keanggotaan sebagai berikut:

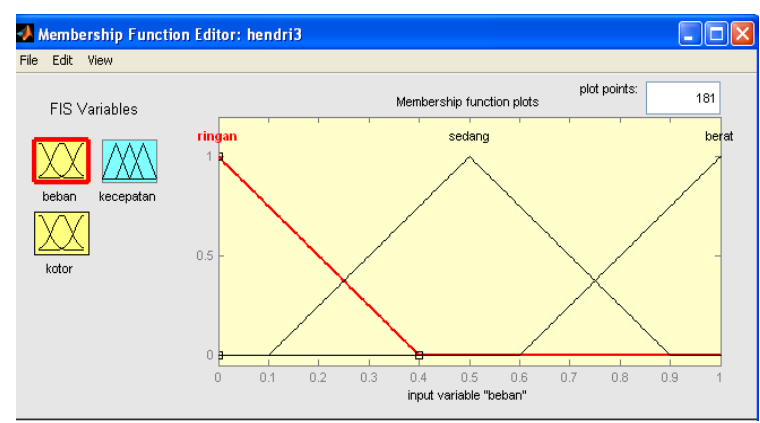

Gambar 12 Representasi Variabel Beban

Pada Gambar 12 diterangkan representasi dari input berupa beban yang berkisar antara 0 dan 1, terdapat tiga fungsi keanggotaan, yaitu pada himpunan ringan $(0-0,4)$, sedang $(0,1-0,9)$, dan berat $(0,6-1)$. 


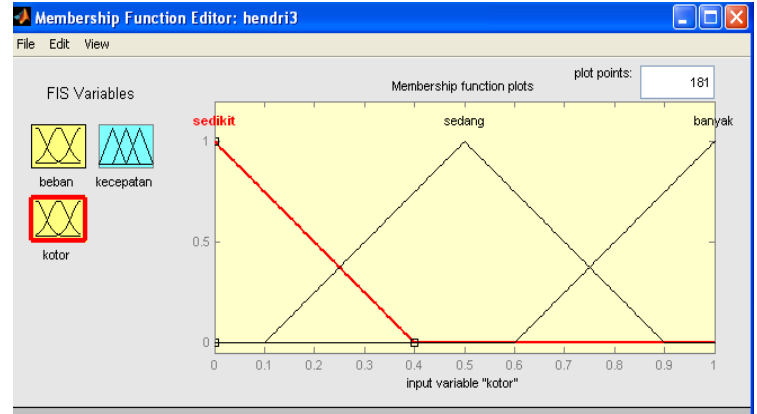

Gambar 13 Representasi Variabel Kotor

Pada Gambar 13 diterangkan representasi dari input berupa kotor yang berkisar antara 0 dan 1, terdapat tiga fungsi keanggotaan, yaitu pada himpunan sedikit (0-0.4), sedang (0.1-0.9), dan banyak (0.6-1).

Sedangkan pada kecepatan sebagau output mempunyai representasi sebagai berikut:

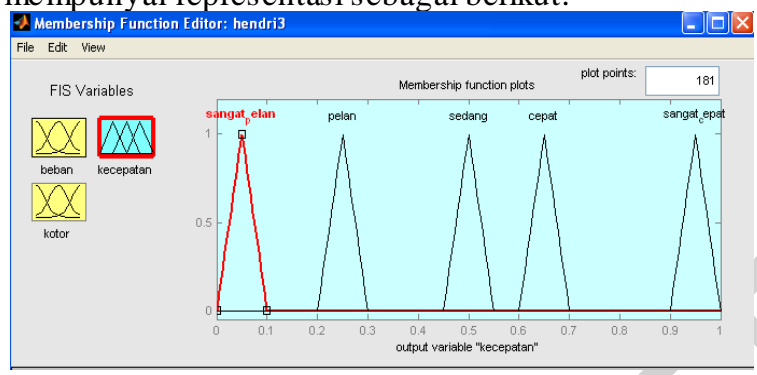

Gambar 14 Representasi Variabel Kecepat an

Gambar 14 merupakan representasi dari variabel yang dikontrol yaitu kecepatan, dimana untuk mendapatkan suatu hasil yang optimal diberikan beberapa suatu fungsi keanggotaan, agar respon yang dikeluarkan pada kecepatan sesuai dengan fungsi keanggotaan. Fungsi keanggotaan terdiri dari, sangat pelan $(0-0.1)$, pelan $(0.2-0.3)$, sedang $(0.45-0.55)$, cepat $(0.6-0.7)$ dan sangat cepat $(0.9-1)$. Disini nilai 0,8 tidak termasuk salah satu fungsi keanggotaan, untuk membuktikan bahwa nilai semesta pembicaraan (nilai di antara 0 dan 1) tidak menitikberatkan pada kefokusan angka, sehingga walaupun nilai tersebut tidak termasuk nilai suatu fungsi keanggotaan, tanggapan pada sinyal kecepatan akan tetap sama. Adapun dengan rule sebagai berikut:

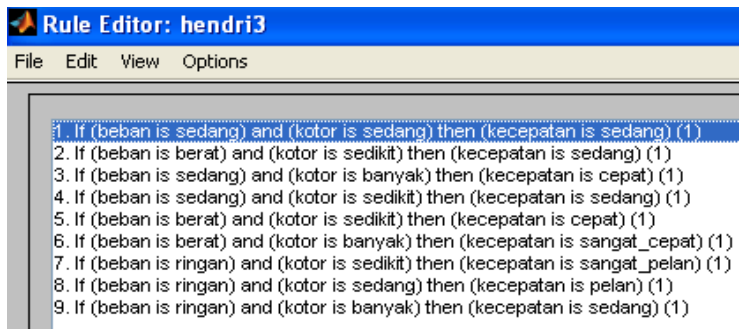

Gambar 15 Representasi Rule Editor
Pada Gambar 15 merupakan IF-THEN rule yang digunakan sebagai acuan untuk menentukan kecepatan sesuai kondisi yang ada.

Setelah mengidentifikasi input dan output beserta rule, disini peneliti mengintegritaskan kendali fuzzy logic dengan pengontrolan PI (proportional integrated), dimana nilai konstanta diperbesar dari percobaan sebelumnya yaitu menjadi $\mathrm{Kp}=75$ dan $\mathrm{Ki}=50$, karena dengan menambah nilai konstanta, dapat memperbaiki respon time, walaupun akan terjadi lonjakan (overshoot) yang besar juga. Hasil respon dari simu lasi yang didapat pada gambar berikut:

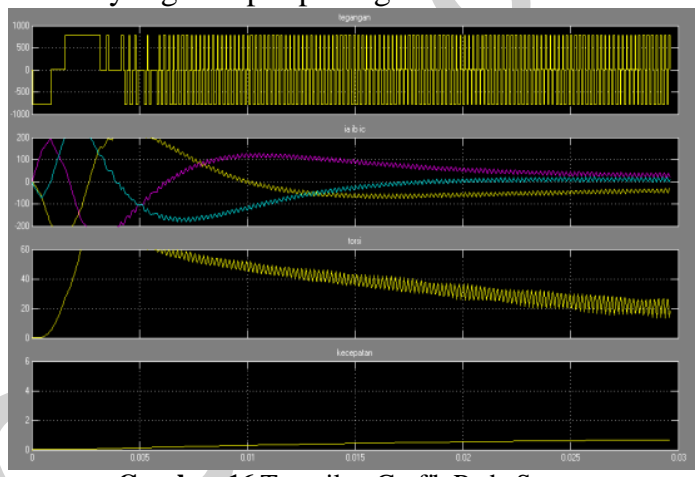

Gambar 16 Tampilan Grafik Pada Scope

Dari Gambar 16 disimpulkan sistem dapat menghasilkan respon tanggapan berupa sinyal grafik yang terdiri dari tegangan, arus (ia ib ic), torsi, dan juga kecepatan. Grafik tegangan, arus (ia ib ic), dan torsi menunjukkan hasil dari desain flux contol dengan pengontrolan PI (proportional integrated) dengan konstanta Kp: 75 dan Ki: 50, in $\mathrm{i}$ memberi pengaruh untuk memberikan keadaan grafik yang halus (tidak patah-patah) saat mengalami kondisi transient pada awal jalan nya simulasi, konstanta ini mengalami overshoot yang tinggi, karena tingginya nilai konstanta pada pengontrolan PI (Proportional Integra-ted), namun dapat mengatasi kondisi respon transient secara cepat dan efisien, sehingga grafik yang dihasilkan bersifat optimal, yaitu grafik dapat berjalan sesuai dengan kondisi sistem, grafik optimal dapat dilihat sebagai berikut:

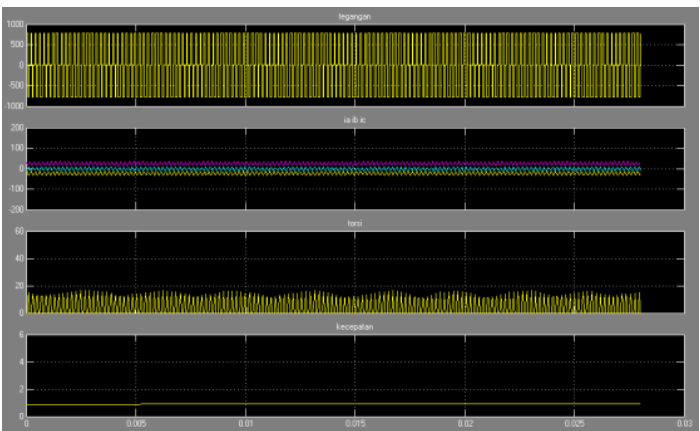

Gambar 17 Tampilan Grafik Optimum Pada Scope 
Gambar 17 merupakan grafik tampilan optimum, dimana sinyal grafik yang dihasilkan berbentuk lurus (tidak berubah).

Pada kecepatan yang dihasilkan, didapatkan suatu grafik yang bersifat fuzzy, dimana rise time tidak didapatkan dengan waktu yang tetap seperti yang didapatkan hasil dari penelitian sebelumnya yang mempunyai nilai rise time tetap, untuk lebih jelasnya dapat dilihat pada grafik berikut:

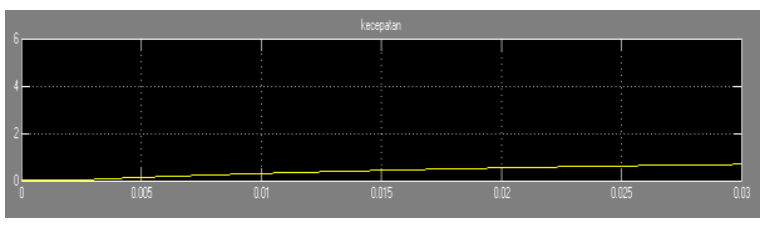

Gambar 18 Tampilan Grafik Kecepatan

Grafik yang dihasilkan pada Gambar 18 menunjukkan bahwa rise time atau kenaikan grafik berupa tangga ini tidak mempunyai nilai tetap, tidak seperti pecobaan sebelumnya yang mempunyai waktu tetap dalam memunculkan rise time, pada grafik ini semakin bertambahnya kemunculan rise time, maka semakin bertambah juga waktu yang dihasilkan setiap waktunya jalan simulasi, ini menandakan bahwa setiap munculnya rise time maka bertambah juga nilai input yang di terima berupa beban dan tingkat kekotoran, sehingga kecepatan yang dihasilkan akan sesuai dengan fungsi keanggotaannya, seperti dalam rule viewer berikut:

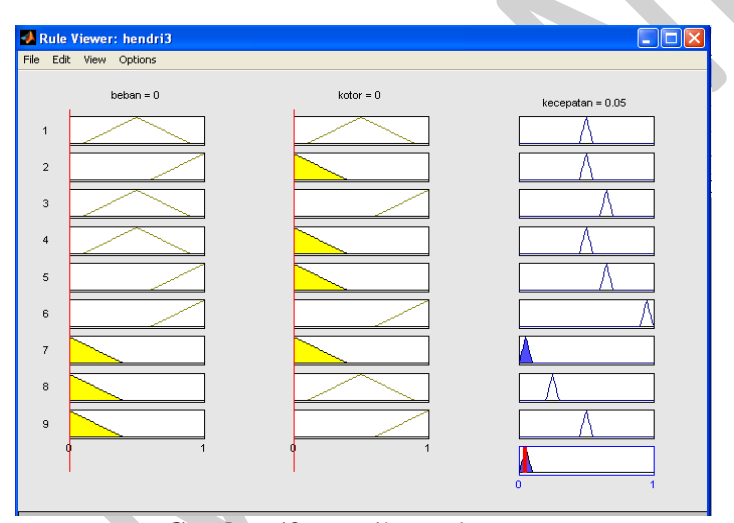

Gambar 19 Tampilan Rule Viewer

Gambar 19 menunjukkan output yang berupa kecepatan sesuai dengan nilai fungsi keanggotaan, ketika input diberi nilai minimal atau nol, kecepatan yang dihasilkan bernilai bersifat minimal juga (mendekati nol).

\section{KES IMPULAN}

Dari penelitian yang telah dilakukan, dapat disimpulkan bahwa:
Kecepatan putaran yang dihasilkan dari fuzzy logic ditentukan oleh input, dimana input yang diaplikasikan adalah beban dan kotor pakaian. Dalam simulink matlab output yang berupa kecepatan menghasilkan grafik, dimana grafik dimulai dari tanpa beban dan kotoran (nilai input minimum), sampai dengan tingkat beban dan kotor pakaian tertinggi (nilai input maximum).

Tanggapan respon pada kecepatan yang dihasilkan bersifat optimal, karena rise time atau kenaikan grafik berupa tangga ini tidak mempunyai nilai tetap atau bervariasi, semakin bertambahnya kemunculan rise time, maka semakin bertambah juga waktu kenaikan rise time yang dihasilkan setiap detiknya, ini menandakan bahwa setiap munculnya rise time maka bertambah juga nilai input yang di terima berupa beban dan tingkat kekotoran.

Nilai semesta pembicaraan, yaitu nilai yang berada di antara 0 dan 1 dapat memberikan respon pada kecepatan yang lebih optimal, karena tidak mentitik-beratkan pada suatu titik angka, sehingga grafik yang dihasilkan sesuai dengan fungsi keanggotaan fuzzy dari input maupun output.

Pemanfaatan Fuzzy Logic seringkali menjadi pilihan terbaik. Walau sudah cukup banyak sistem kontrol yang sudah bekerja dengan baik tanpa fuzzy logic, metode ini sangat tergantung pada kebiasaan pemakaian seorang pengguna, jika sering menggunakan metode ini bahwa akan mengemukakan fuzzy logic adalah sebuah metode yang solid dan efisien untuk memecahkan masalah pemetaan yang memprioritaskan kepresi-sian

\section{REFERENS I}

[1]. Agus Naba, Belajar cepat Fuzzy Logic Menggunakan Matlab, C.V Andi Offset, Yogyakarta, 2009.

[2]. Felix Pasila Limboto dan Bayu Krisnawan, “Desain Flux Vector Control Inverter 3 Fasa Pada Motor Induksi 1.5 HP Menggunakan Power Blockset"

[3]. Frans Kurniadi, "Simulasi Fuzzy Logic Control Pada Mesin Cuci Menggunakan Simulink Matlab",

[4]. Gunaidi Abdia Away, Matlab Programming, Informatika, Bandung, 2010.

[5]. Heru Supriyono dan Rochmad Rosyidi, "Implementasi Pengen-dalian Kecepatan Motor DC Dengan Pengendali Fuzzy-PID Menggunakan RealTime Windows Target Matlab 6.5", Jurnal Penelitian Sains \& T eknologi, Vol. 9, 2008, pp. 165-176.

[6]. Rudy S. Wahyudi, "Estimasi sistem orde dua dengan menggu-nakan Perangkat Lunak Matlab", Jurnal Teknik Elektro Trisakti, vol.1, Nomor.1. Agustus 2010, pp. 17-24.

[7]. Sri Kusumadewi, Analisis \& Desain Sistem Fuzzy Meggunakan Tool Box Matlab, Graha Ilmu, Yogyakarta, 2002. 